\title{
Effects of Agricultural Inputs Use on Agricultural Productivity in Nepal: An Empirical Study
}

\author{
Sujan Ghimire*, Ananta Dhakal \\ Department of Agricultural Economics and Agribusiness Management, Agriculture and Forestry University, Chitwan, Nepal
}

\section{Email address:}

sghimire225@gmail.com (S. Ghimire)

${ }^{*}$ Corresponding author

\section{To cite this article:}

Sujan Ghimire, Ananta Dhakal. Effects of Agricultural Inputs Use on Agricultural Productivity in Nepal: An Empirical Study. International Journal of Agricultural Economics. Vol. 6, No. 5, 2021, pp. 212-217. doi: 10.11648/j.ijae.20210605.12

Received: February 14, 2021; Accepted: March 8, 2021; Published: October 5, 2021

\begin{abstract}
Agricultural inputs have crucial role to deliver increased productivity and sustained agricultural growth in an economy. However, adequate empirical research is not available related to effects of agricultural inputs use on agricultural productivity in Nepalese context. Thus, empirical study was conducted so as to reveal the effects of agricultural inputs use in agricultural production sector. This study utilized time series data of 30 years (1990 to 2019) retrieved from various secondary data sources of agricultural input supply in Nepal. Then, data obtained were processed and analyzed in two ways: First, Compound Annual Growth Rate (CAGR) of different agricultural inputs were estimated using Log-Lin regression model. Second, the parameters estimates of Cobb-Douglas regression analysis was obtained taking Agricultural GDP as the dependent variable and independent variables viz. cultivated area, irrigated area, population engaged in agriculture, fertilizer consumption, pesticides application, improved seeds used and government expenditure. The results depicted that growth rate of various agricultural inputs use had raised significantly and was in increasing trend during the study period. Furthermore, cultivated area, irrigated area and pesticides application were found statistically significant and had significant impact on growth of agricultural GDP (Gross Domestic Product).
\end{abstract}

Keywords: Compound Annual Growth Rate (CAGR), Agricultural GDP (Gross Domestic Product), Cobb-Douglas Production Function

\section{Introduction}

Agriculture is mainstay to Nepalese economy contributing 26.5 percent to the country's GDP, employing 65.6 percent of the economic active population in the country [15]. However, share of agriculture in Nepal's GDP has been declining in the recent years accounting less than a third of GDP [19]. Agricultural sector contribution to GDP is gradually declining, whereas that of non-agricultural sector is increasing every year [26].

Agricultural productivity is the output determined by required inputs level in agricultural production sector of a particular nation using available technology in specific period of time [10]. Comparatively there is lower agricultural productivity in developing economies compared to developed economies due to low investment in research and development of agricultural inputs. Moreover, there is meager supply of agricultural inputs viz. land, labour, capital, fertilizers, improved seedlings and technology adoption [2].

In Nepal, the growth in agricultural sector relies on major staple food grains and production of few commercial crops. In addition, improved seeds supply, fertilizer application, adequate irrigation systems and favorable weather conditions also support the agricultural growth [19]. Stagnant growth in recent years in agriculture sector is aligned with farming systems highly relied on weather patterns, inadequate facilities of irrigation, lack of inputs supply, and uncontrolled trend of land fallowing and abandonment practices across the country [16]. Therefore, this empirical study was carried out with an aim to overview the growth of agricultural inputs use trends, in area and production of major crops. Also, Impacts analysis of agricultural inputs contribution on growth of agricultural 
GDP is the major concern of the research.

\section{Methodology}

During the study, data were collected from various secondary sources: MoALD (Ministry of Agriculture and Livestock Development), DoA (Department of Agriculture), ABPSD (Agribusiness Promotion and Statistics Division), NRB (Nepal Rastra Bank), Economic Surveys. The data spans the period 1990 to 2019 (30 years). The study period was categorized in to Period I (1990 to 1999), Period II (2000 to 2009) and Period III (2010 to 2019). Thus, the obtained information were sequentially tabulated, coded and analyzed with the help of computer software: STATA (Version 14).

\subsection{Analytical Models}

In order to determine Compound Annual Growth Rate (CGR), growth model was used. Cobb Douglas production function determined the Agricultural Gross Domestic Product (AGDP).

\subsection{Compound Annual Growth Rate (CAGR)}

The trend in growth of agricultural inputs was determined using CAGR (Compound Annual Growth Rate). Y denotes the observation (e.g Gross Irrigated Area) at time $t$ and $r$ is compounded growth rate. Model used for estimating the CAGR (Compound Annual Growth Rate) is based on the equation:

$$
\mathrm{Y}=\mathrm{Y}_{0}(1+\mathrm{r})^{\mathrm{t}}
$$

Now, In order to determine the CAGR (Compounded

$$
\log Y=\log \beta_{0}+\beta_{1} \log X_{1}+\beta_{2} \log X_{2}+\beta_{3} \log X_{3}+\beta_{4} \log X_{4}+\beta_{5} \log X_{5}+\beta_{6} \log X_{6}+\beta_{7} \log X_{7}
$$

Where,

$\mathrm{Y}=$ Agricultural Gross Domestic Product (At Factor Cost, NRs in Million at Constant Prices)

$\mathrm{X}_{1}=$ Total Cultivated Area (hectares)

$\mathrm{X}_{2}=$ Total Fertilizer Consumption (tones)

$\mathrm{X}_{3}=$ Number of Population Engaged in Agriculture

$\mathrm{X}_{4}=$ Government Expenditure in Agriculture (NRs in Million)

$\mathrm{X}_{5}=$ Total Improved Seed Used (tones)

$\mathrm{X}_{6}=$ Total Pesticides Application (tones)

$\mathrm{X}_{7}=$ Total Irrigated Area (hectares)

$\beta_{0}=$ Coefficient

\subsection{Multicollinearity Diagnosis}

Time series production analysis of data may often lead to multicollinearity problem. It is a linear relationship among the independent variables used in the regression model. In order to check multicollinearity, pairwise correlation matrix for all explanatory variables was prepared. The rule of thumb, according to Heady and Dillion (1961), is that, the correlation coefficient between a pair of independent
Annual Growth Rate), the model is linearized by means of natural logarithmic transformation i.e. Log-Lin regression function:

$$
\log _{\mathrm{e}}(\mathrm{Y})=\beta_{0}+\beta_{1}(\mathrm{~T})+\mathrm{e}_{\mathrm{i}}
$$

$\mathrm{Y}=$ Dependent Variable Agricultural GDP

$\beta_{0}=\log _{\mathrm{e}}(\mathrm{Y} 0)$ Intercept

$\beta_{1}=\log _{\mathrm{e}}(1+\mathrm{r})$ Regression Coefficient of time variable

$\mathrm{T}=$ Time Variable in years $(1,2,3 \ldots)$

$\mathrm{e}_{\mathrm{i}}=$ disturbance term

Now, the model is fitted with the data and finally CAGR (Compounded Annual Growth Rate) is estimated as [22]:

$$
\mathrm{CAGR}=100 *\left[\mathrm{e}^{(\beta 1)}-1\right]
$$

\subsection{Cobb-Douglas Regression Function}

Agricultural inputs impacts on agricultural GDP (Gross Domestic Product) was studied using Cobb-Douglas regression function. In agriculture production economics, the Cobb- Douglas functional form is hugely used due to its theoretically fitted computational parameters. It was given by Knut (1926) and further developed by Charles Cobb and Paul Douglas [5].

$$
\mathrm{Y}=\beta_{0} \mathrm{X}_{1}^{\beta 1} \mathrm{X}_{2}^{\beta 2} \mathrm{X}_{3}^{\beta 3} \mathrm{X}_{4}^{\beta 4} \mathrm{X}_{5}^{\beta 5} \mathrm{X}_{6}^{\beta 6} \mathrm{X}_{7}^{\beta 7}
$$

Where, $\mathrm{Y}$ is dependent variable (Agricultural Gross Domestic Product) and $X_{1}$ through $X_{7}$ are Agricultural inputs respectively. Since, the production function is non-linear, for OLS (Ordinary Least Square Method) estimation, logarithmic transformation was done [12];

\section{Results and Discussion}

\subsection{Compounded Growth Rate of Agricultural Inputs (Percent per Annum)}

Using the CAGR (Compounded Annual Growth Rate) technique, the use of agricultural inputs trend was estimated as represented by table 1 . The significant results of the growth rates depicted that the agricultural inputs use have considerably increased in the recent years. Gross irrigated area had increased significantly by 7.3 percent over the years. Some extra area of cultivable land is irrigated every year, but still, the country is not able to irrigate all arable land. Most of the farmers are relying on rain-fed farming, irrigation is yet another critical input to lengthen harvest period and diversify commodities [18]. The low productivity of the agricultural sector is associated with the inadequacy of irrigation facilities. Major crops are highly dependent on rainfall due to limited provision of year round irrigation water i.e. only 55 percent of agricultural land is irrigated [17]. 
Table 1. Compound Growth Rates of Different Agricultural Inputs (Percent/annum).

\begin{tabular}{|c|c|c|c|c|}
\hline Agricultural Inputs & $\begin{array}{l}1990 \text { to } 1999 \\
\text { (Period I) }\end{array}$ & $\begin{array}{l}2000 \text { to } 2009 \\
\text { (Period II) }\end{array}$ & $\begin{array}{l}2010 \text { to } 2019 \text { (Period } \\
\text { III) }\end{array}$ & $\begin{array}{l}\text { Overall Period } \\
(1990 \text { to 2019) }\end{array}$ \\
\hline Gross Irrigated Area (hectares) & $8.39 * *$ & -0.45 & $20.50 * *$ & $7.3 * *$ \\
\hline Improved Seeds (Mt) (Total) & 5.92 & $15.61 *$ & $69.82 *$ & $9.39 * *$ \\
\hline Rice & 26.47 & $52.05 * *$ & $33.04 *$ & $29.12 * *$ \\
\hline Wheat & 1.85 & 22.17 & $19.39 *$ & $7.64 * *$ \\
\hline Maize & 18.57 & 22.17 & $895.40 * *$ & -12.7 \\
\hline Lentil & $26.18^{*}$ & $-54.39 *$ & -17.39 & $-14.88 * *$ \\
\hline Population Engaged in Agriculture & $5.43 * *$ & 0.46 & 3.99 & 3.75 \\
\hline Pesticides (tones) & $5.43 *$ & $21.89 *$ & $28.52 * *$ & $26.76 * *$ \\
\hline Fertilizers Consumption (tones) & -7.74 & $-37.62 * *$ & $89.67 * *$ & 1.85 \\
\hline Urea & -8.58 & $46.17 *$ & $92.3 *$ & 7.89 \\
\hline DAP & $137.61^{*}$ & $-46.9 * *$ & $107.49 * *$ & $17.21 *$ \\
\hline Potash & 14.02 & 4.23 & $87.93 * *$ & 9.39 \\
\hline Government Expenditure in Agriculture (NRS Million) & $3.03 * *$ & $22.46^{*}$ & $45.54 * *$ & $5.43 *$ \\
\hline
\end{tabular}

Notes: ** Significant at $1 \%$ level of significance, * Significant at $5 \%$ level of significance.

Total use of improved seed of major cereal crops (rice and wheat) also increased in overall three decades. The overall annual growth rate for these crops were rice (29.12 percent) and wheat (7.64 percent) respectively. On the other hand, use of improved seeds for maize and lentil had decreased considerably. National Seed Company Ltd. (NSC) distributes improved and quality seeds to the commercial farmers. The company harvests quality seeds from its own farms and that of the farmers and sell them at the market after seed treatment. Fluctuation in supply of improved seed has been witnessed every year. There is inadequate reliable improved seeds supply, which contributes to low seed replacement rate (SRR) viz. 4\%, 4-8\%, 3.8\%, 1.6\% for rice, wheat, maize and pulses respectively despite having the desired rate of $(25 \%$ to $30 \%)$ [23].

The use of chemical fertilizers urea, DAP, potash had shown a positive growth of $7.89,17.21,9.39$ percent respectively. The shortage of chemical fertilizer directly affects agricultural production. Agriculture Inputs Company Ltd. (AIC) distributes and sells chemical fertilizers across the country. AIC and Salt Trading Corporation funded by Nepal government distributes subsidized chemical fertilizer through cooperatives and private dealers across nation. This aids about 35 percent of total requirements while rest comes from other sources [14]. Low adoption of resistance variety to insect-pest and lack of consciousness to health has increased pesticides by 26.76 percent [20].

There is no significant rise in the number of economic active population engaged in agriculture over the years. The net cultivated area in agriculture sector is in decreasing trend. Land use planning policy being unscientific, most of the agricultural land is transformed for non-agricultural activities leading to shrinkage of cultivable area. Exodus in youth migration to urban areas has contributed to abandonment of land in countryside. Most of the rural working age population are displaced to urban cities and abroad creating a vacuum of agriculture labor that has highly affected agricultural productivity [8]. Thapa (2012) in his research found that countryside people with greater household number and less per capita income tends to migrate more. Although huge investment-planning in recent years has been done in agricultural sector, there is still decreasing production and low involvement of economic active population in this sector [24]. This shift of economic active population in an economy from agriculture to other sector is not natural and is unsustainable since Nepalese economy is typically rooted on traditional knowhow, culture, and lifestyle [21].

The budget expenditure estimated by Nepalese government in agriculture meagerly increased by 5.43 percent in the recent years.

\subsection{Growth Rate in Crop Area}

The compounded growth rate of area of principal crops are as shown in table 2. Positive growth rates in area observed are rice (0.23), maize (15.08), millet (2.32), wheat (1.85), oilseeds (2.80), potato (5.19), sugarcane (7.39) and pulses (1.15). The area of cultivation under barley, tobacco, jute and cotton decreased by $2.05,14.09,26.71$ percent respectively. Area under jute cultivation and its production have declined due to less availability of seeds [19]. Farmers are reluctant to jute cultivation because of drudgery in extracting decayed fibers and due to necessity of large labor for raw jute production. Cotton cultivation is in decreasing trend accompanied by reduction in number of committed buyers of harvested leaves [7].

\subsection{Growth Rates in Production}

Table 3 shows production trend of major crops grown in the country. The growth rate per annum in production was positive for rice (3.99), maize (5.68), wheat (8.14), oilseeds (7.64), potato (14.02), sugarcane (9.9) and pulses (6.65). However, the production of millet (0.22), barley (28.5), tobacco (9.0), jute (1.14) and cotton (24.83) experienced negative growth. Major cash crops sugarcane and potato contributes about 50 percent and 47 to the total production. In the past, sugarcane farmers were reluctant in sugarcane farming because they could not cover their breakeven, but 
now they are willing to cultivate due to their price premium and increasing demand [9]. Area of barley production has decreased considerably in the recent years due to the fact that farmers prefer other crops to barley production. Farmers interested in tobacco cultivation is fading away resulting in low production. Due to continual rainfall during winter season, a fall in pulses gross production has been on the continuous decline in the past years [21].

Table 2. Compounded Growth Rates of Area of Major Crops (Percent per annum).

\begin{tabular}{|c|c|c|c|c|}
\hline Crops & 1990 to 1999 (Period I) & 2000 to 2009 (Period II) & 2010 to 2019 (Period III) & Overall Period (1990 to 2019) \\
\hline Rice & 2.32 & -0.45 & -0.22 & 0.23 \\
\hline Maize & -7.1 & $49.62 * *$ & $2.09 *$ & $15.08 * *$ \\
\hline Millet & $10.15 * *$ & $3.75 * *$ & $-4.28 * *$ & $2.32 * *$ \\
\hline Wheat & $3.03 * *$ & $2.09 * *$ & $-1.59^{*}$ & $1.85^{* *}$ \\
\hline Barley & 5.43 & $-2.27 * *$ & -2.72 & $-2.05 * *$ \\
\hline Oilseeds & $5.92 * *$ & $-1.14 * *$ & $3.99 *$ & $2.80 * *$ \\
\hline Potato & $10.91 * *$ & $8.39 * *$ & -8.16 & $5.19 *$ \\
\hline Tobacco & $11.4 * *$ & $-13.70 * *$ & -8.336 & $-14.09 *$ \\
\hline Sugarcane & $13.76 * *$ & 35.2 & $6.41 *$ & $7.39 * *$ \\
\hline Jute & -3.83 & -2.05 & $-36.17 *$ & -1.59 \\
\hline Cotton & 4.47 & -48.11 & -4.9 & $-26.71 * *$ \\
\hline Pulses & $2.80 * *$ & $1.15^{* *}$ & -0.45 & $1.15^{* *}$ \\
\hline
\end{tabular}

**, * Significant at $1 \%$ and $5 \%$ level of significance respectively.

Table 3. Compounded Growth Rates of Production of Major Crops (Percent per annum).

\begin{tabular}{|c|c|c|c|c|}
\hline Crops & 1990 to 1999 (Period I) & 2000 to 2009 (Period II) & 2010 to 2019 (Period III) & Overall Period (1990 to 2019) \\
\hline Rice & 3.75 & 0.69 & $5.68^{*}$ & $3.99 * *$ \\
\hline Maize & 26.67 & $8.14 * *$ & $7.89 * *$ & $5.68 *$ \\
\hline Millet & -12.5 & $2.09 *$ & 0.69 & -0.22 \\
\hline Wheat & $9.14 * *$ & $6.16^{* *}$ & $4.23 *$ & $8.14^{* *}$ \\
\hline Barley & 67.88 & $-72.26 * *$ & 0 & $-28.5^{* *}$ \\
\hline Oilseeds & $7.64 * *$ & 2.09 & $13.76^{* *}$ & $7.64 * *$ \\
\hline Tobacco & $-13.9 * *$ & $-12.09 * *$ & -3.39 & $-9.00 * *$ \\
\hline Sugarcane & $16.94 * *$ & $3.99 * *$ & $10.15^{* *}$ & $9.9^{* *}$ \\
\hline Jute & -1.37 & $2.56^{* *}$ & -7.5 & -1.14 \\
\hline Cotton & -12.9 & -46.91 & -2.72 & $-24.83 * *$ \\
\hline Pulses & $6.16^{* *}$ & $2.56^{*}$ & $7.64 * *$ & $6.65 * *$ \\
\hline
\end{tabular}

**, * Significant at $1 \%$ and $5 \%$ level of significance respectively.

\subsection{Impacts of Agricultural Inputs on AGDP (Agricultural Gross Domestic Product)}

Table 4 illustrates the parameter estimates of regression models for AGDP (Agricultural Gross Domestic Product) with different explanatory variables.

Cobb-Douglas production function was taken for estimating parameters of explanatory variables in regression analysis. The coefficients along with different estimates of parameters in the functional model are as shown in Table 4. The coefficient of multiple determination $\left(\mathrm{R}^{2}\right)$ of the model was $0.90 \mathrm{R}^{2}$ value. It illustrates that on an average 90 percent of the total variation in AGDP (Agricultural Gross Domestic Product) was explained by the independent variables used in the model. The larger $\mathrm{R}^{2}$ value of 0.90 depicts better fitness of the regression model [11].

Table 4. Parameters estimates of regression models for AGDP (Agricultural Gross Domestic Product).

\begin{tabular}{|c|c|c|c|c|c|}
\hline \multirow{2}{*}{ Explanatory variables } & \multicolumn{2}{|c|}{ Unstandardized coefficients } & \multirow{2}{*}{$\begin{array}{l}\text { Standardized coefficients } \\
\text { Beta }\end{array}$} & \multirow{2}{*}{ t-value } & \multirow{2}{*}{ p-value } \\
\hline & B & SE & & & \\
\hline Intercept & -74.02 & 13.456 & & -5.464 & 0 \\
\hline Log Gross Cultivated Area (hectare) & 0.625 & 0.789 & 0.495 & 5.864 & $0.006 * *$ \\
\hline Log Total Population engaged in agriculture & 0.169 & 0.134 & 0.094 & 1.262 & 0.22 \\
\hline Log Total Fertilizer consumption (tones) & -0.036 & 0.119 & -0.038 & -0.3 & 0.0 .767 \\
\hline Log Gross Irrigated Area (hectare) & 0.256 & 0.373 & 0.349 & 2.295 & $0.032 *$ \\
\hline Log Total Improved Seeds Used (tones) & 0.144 & 0.123 & 0.121 & 1.168 & 0.225 \\
\hline Log Total Pesticides Application & 0.337 & 0.119 & 0.469 & 3.176 & $0.004 * *$ \\
\hline
\end{tabular}

Regressand: AGDP SE $=$ Standard error

Value of $\mathrm{R}=0.950, \mathrm{R}^{2}=0.900$, Adjusted $\mathrm{R}^{2}=0.8800$ and standard error $=0.02610$, Durbin-Watson test for test of autocorrelation $=2.221$ and $\mathrm{F}$ value $=50.322 * *$ **, * Significant at $1 \%$ and $5 \%$ level of significance respectively. 
$\mathrm{F}$ value was found to be 50.322 and is significant at 1 percent level implying a better fit of the regression model. From the results illustrated in the table, parameter coefficients of Gross Cultivated Area, Gross Irrigated Area and Total Pesticide Application had significant and positive relationship, however, Total Fertilizer Consumption had negative and insignificant relationship with AGDP. Total population engaged in agriculture showed no significant relation with AGDP.

From the results, we can infer that, 1 percent increment in net cultivated area would increase the AGDP on an average by 0.625 percent significantly keeping other variables constant. Values illustrates that one percent increment in a unit of irrigated land would raise AGDP on an average by 0.25 percent remaining other factors constant. The estimates coefficient infer that the one percent greater application of pesticides would increase the AGDP on an average by 0.33 percent which is statistically significant at $1 \%$ level.
In addition, the sum of coefficients of the production function estimates is 1.149 , indicating the increasing return to the scale of production. Similarly Wagle in his study found the similar relationship between the use of agriculture inputs and GDP growth of Nepal and revealed significant relationship between agricultural inputs use with economic growth of Nepal [25].

In his study Thapa identified use of chemical pesticides, improved seeds as important factors contributing in agricultural growth in Nepal [24]. Similarly, in a study, net cultivated area, total irrigated area, quality seed distribution and import of pesticides showed significant impact on AGDP growth [3].

\subsection{Zero Order Correlation Matrix of Variables}

As presented in table 5, correlation coefficients between explanatory variables did not exceed 0.8 implying no multicollinearity.

Table 5. Pairwise correlation matrix of explanatory variables.

\begin{tabular}{|c|c|c|c|c|c|c|c|}
\hline Variables & $\begin{array}{l}\text { Gross } \\
\text { Cultivated } \\
\text { Area } \\
\end{array}$ & $\begin{array}{l}\text { Population } \\
\text { Engaged in } \\
\text { Agriculture }\end{array}$ & $\begin{array}{l}\text { Total } \\
\text { Fertilizer } \\
\text { Application }\end{array}$ & $\begin{array}{l}\text { Gross } \\
\text { Irrigated } \\
\text { Area } \\
\end{array}$ & $\begin{array}{l}\text { Total } \\
\text { Improved } \\
\text { Seeds Used } \\
\end{array}$ & $\begin{array}{l}\text { Total } \\
\text { Pesticides } \\
\text { Application }\end{array}$ & $\begin{array}{l}\text { Government } \\
\text { Expenditure }\end{array}$ \\
\hline Gross Cultivated Area & 1.00 & 0.223 & 0.452 & 0.321 & 0.214 & 0.356 & 0.141 \\
\hline Population Engaged in Agriculture & - & 1.00 & 0.021 & 0.145 & 0.478 & 0.245 & 0.023 \\
\hline Total Fertilizer Application & - & - & 1.00 & 0.521 & 0.329 & 0.222 & 0.158 \\
\hline Gross Irrigated Area & - & - & - & 1.00 & 0.547 & 0.645 & 0.299 \\
\hline Total Improved Seeds Used & - & - & - & - & 1.00 & 0.231 & 0.365 \\
\hline Total Pesticides Application & - & - & - & - & - & 1.00 & 0.424 \\
\hline Government Expenditure & - & - & - & - & - & - & 1.00 \\
\hline
\end{tabular}

\section{Conclusion}

The growth rate of agricultural inputs use had increased significantly for some variables during the study period. The gross irrigated area, improved seed of major cereal crops had significant increment in their growth rates. However, this sluggish growth rate is not satisfactory in order to achieve targeted AGDP. Chemical fertilizers use had shown a positive growth, yet having acute dearth during planting season. In addition, the use of pesticides have increased considerably, neglecting health issues and awareness among farmers and consumers. Moreover, there is no significant increment in the active labor force engaged in agricultural sector over the years. The net cultivated area is in decreasing trend contributed by migration and land fragmentation. The growth rates of cultivated area, irrigated area and pesticides application were found statistically significant and had significant impact on growth of agricultural GDP (Gross Domestic Product). Therefore, from the study it is concluded that, the aimed AGDP can be achieved only by increased use of agricultural inputs. Concerning the importance of agricultural inputs use, the government should facilitate adequate supply of agricultural inputs to farmers that can only lead to a sustained agricultural and economic growth in the country.

\section{References}

[1] ADB. (2014). Effects of Migration and Remittances in Nepal's Agriculture Yield. Asian Development Bank.

[2] Agriscope. (2008). Production of Annual Crops in Nigeria. Agriscope Newsletter of the Federal Department of Agriculture, 12 (ISSN. No. 886-1006).

[3] Awan, F. and Mustafa, U. (2013). Key factors contributing to agricultural growth in Pakistan: An application of time series analysis. Journal of Agricultural Economics and Development, 1 (12): 6-13.

[4] CBS. (2011). Nepal Living Standard Survey. Central Bureau of Statistics, Kathmandu, Nepal.

[5] Cobb CW, Douglas PH (1928). (n.d.). A Theory of Production. American Economic Review, 139-165. Retrieved from https://goo.gI/5T5FTG

[6] DoA. (2017). Department of Agriculture, Government of Nepal, Harharbhawan, Lalitpur, Nepal.

[7] DoA. (2018). Deaprtment of Agriculture, Harharbhawan, Lalitpur, Nepal.

[8] FAO. (2017). Biosecurity Status of Food and Agriculture in Nepal, Food and Agriculture Organization, Rome, Italy. 
[9] FNCCI. (2019). Federation of Nepalese Chambers of Commerce and Industries, Kathmandu, Nepal.

[10] Fulginiti LE, Richard KP. (1998). Agrcultural Productivity in Developing Countries. Retrieved from https://goo.gI/T19aG

[11] Gomez, K. A. and Gomez, A. A.. (1984). Statistical Procedure for Agriculture Research, Second Edition. John Wily and Sons Inc. New York.

[12] Gujrati, D. N., Porter, D. C., \& Gunasekar, S.. (2012). Basic Econometrics.

[13] Heady, E. O. and J. L. Dillion. (1961). Agricultural Production Function. Down State University Press, Iowa, USA.

[14] IFPRI. (2019). Use of Chemical Fertilizers in Nepal: Issues and Implications.

[15] MoAD. (2018). Krishi Diary, GoN, MoAD, Agriculture Information and Communication Centre, Haribhawan, Lalitpur.

[16] MoALD. (2019). Ministry of Agriculture and Livestock Development, Singhadurbar, Kathmandu, Nepal.

[17] MoEWRI. (2018). Ministry of Energy, Water Resources and Irrigation, Singhadurbar, Kathmandu, Nepal.
[18] MoF. (2017). Economic Survey 2017. Ministry of Finance, Singhadurbar, Kathmandu, Nepal.

[19] MoF. (2018). Economic Survey 2018. MInistry of Finanace, Singhadurbar, Kathmandu, Nepal.

[20] MoHP. (2017). Ministry of Health and Polpulation, Singhadurbar, Kathmandu, Nepal.

[21] Satyal, V. (2011). Agriculture in Decline. Journal of Development Issues. Vol. 11 pp. 1-8.

[22] Sendhil, R. (2012). Production and Export Performance of Onions- An Exploratory Study. 69 (7), 355-362.

[23] SPQCC. (2018). Seed Promotion and Quality Control Center, Kathmandu, Nepal.

[24] Thapa, Y. (2011). Agrciultural Growth: Lessons for Residing Principles. Nepalese Journal of Agricultural Economics.

[25] Wagle, T. (2014). Agriculture Production in Nepal: A theoretical and an Empirical Analysis, Saraswati Multiple Campus, TU: Journal of Development Review, Vol 3, pp 160165.

[26] WB. (2019). World Bank Database, Retrieved from https://data.worldbank.org. 